\title{
INFLUENCE OF CONCRETE-PICTORIAL-ABSTRACT (CPA) APPROACH TOWARDS THE ENHANCEMENT OF MATHEMATICAL CONNECTION ABILITY OF ELEMENTARY SCHOOL STUDENTS
}

\author{
Hafiziani Eka Putri ${ }^{1}$, Misnarti ${ }^{2}$, Ria Dewi Saptini ${ }^{3}$ \\ Universitas Pendidikan Indonesia, Kampus Purwakarta
}

\begin{abstract}
The study aims to examine the influence of CPA learning approach towards the enhancement of mathematical connection ability of elementary school students. The present research is a quasi experiment using pretest and posttest design controls in Mathematics applied to 39 elementary school students in Purwakarta, West Java, Indonesia. The results of the study show that mathematical connection ability of elementary school students who were taught using CPA learning approach is enhanced than the elementary school students who were taught using conventional learning as a whole group of high and low achiever students according to their mathematical prior ability.
\end{abstract}

Keyword: Mathematical connection ability, CPA learning approach.

\begin{abstract}
Abstrak: Penelitian ini bertujuan untuk menguji pengaruh pendekatan pembelajaran CPA terhadap peningkatan kemampuan koneksi matematika siswa sekolah dasar. Penelitian ini adalah kuasi eksperimen dengan menggunakan kontrol desain pretest dan posttest dalam Matematika diterapkan kepada 39 siswa sekolah dasar di Purwakarta, Jawa Barat, Indonesia. Hasil penelitian menunjukkan bahwa kemampuan koneksi matematika siswa sekolah dasar yang diajarkan menggunakan pendekatan pembelajaran CPA lebih meningkat daripada siswa sekolah dasar yang diajar menggunakan pembelajaran konvensional secara keseluruhan dalam kelompok siswa berprestasi tinggi dan rendah sesuai dengan kemampuan matematika mereka sebelumnya.
\end{abstract}

Kata Kunci: Kemampuan koneksi matematis, pendekatan pembelajaran CPA.

\section{INTRODUCTION}

The background of the present study is the existence of gap between the expectation of curriculum and the reality of mathematics learning in Indonesia elementary schools. Stated in the curriculum objective, Indonesia elementary school students who are learning mathematics are expected to master mathematical ability, for example, mathematical connection ability (Depdiknas, 2006; Permendikbud Number 81A Year 2013). The importance of mathematical connection ability is stated clearly by NCTM (2000) that mathematical connection helps students to develop their perspective, seeing mathematics as an

\footnotetext{
' UPI Kampus Purwakarta, Email: hafizianiekaputri国upi.edu

2 SDN 37 Tanjungpandan

${ }^{3}$ UPI Kampus Purwakarta
}

integrated part of a group of topics and admitting relevance and application both in and outside the classroom. However, the reality based on previous studies show that mathematical connection ability of Indonesia elementary school students is still low (Suwandari, 2015; Saptini, 2016). Based on this situation, improvement should be made to enhance students' mathematical connection ability.

The enhancement of elementary school students' mathematical connection ability can be done through appropriate learning approach. Elementary school students who are, in average, between 7-12 years old are still in concrete operational stage as stated by Piaget (in Desmita, 2008) 
that in this particular age, the students think logically about the concrete events and classify materials into different shapes. Mathematics learning which is taught to the students in elementary school must use something real and concrete so that students are expected to be able to understand the learning better especially to be able to understand the connection in the daily use. One of the learning approaches thought to be appropriate to enhance the mathematical connection ability of elementary school students is CPA approach.

Concrete-Pictorial-Abstract is an approach in mathematics learning that is conducted in stages. Every stage is developed upon the previous stage and because of that it should be conducted in order.CPA learning consists of three learning stages i.e. learning through physical manipulation of concrete materials, learning through pictorial representation of concrete materials manipulation, and problem solving using abstract notation (Witzell, 2005).The findings of study by Witzel (2005) upon students of grade six and seven who are identified to have learning algebra difficulty conclude that students who learn to solve algebra equation transformation through CPA approach obtain higher test result than the students of class control (who received traditional learning).It is in line with the study of Putri (2015) which concludes that the implementation of CPA approach in mathematics learning can enhance the ability of mathematical representation, spatial sense, and selfefficacy of students who are going to be elementary school teachers.

Some previous studies found interaction between the learning approach implemented and the mathematical prior ability with the achievement or enhancement of certain mathematical ability. For example, study conducted by Surya (2013) shows that there is a significant interaction between contextual learning approach and students group of Mathematical Prior Ability (MPA) to the improvement of visual thinking representation ability. Furthermore, study of Dwirahayu (2012) states that there is an interaction between explorative learning strategy and students' MPA to the improvement of visualization ability. Therefore, it is important to investigate the influence of the implementation of CPA approach in mathematics learning in every level of MPA group to enhance the ability of students' mathematical connection ability.

According to the elaboration above, the writer is motivated to conduct a study focused on the effort to enhance mathematical connection ability of elementary school students through CPA approach learning. Hopefully, the findings of the present study could give benefit both for teachers in conducting mathematical learning in class and for other researchers who are interested in developing mathematical learning.

\section{LITERATURE REVIEW \\ Mathematical connection ability}

Mathematical connection ability can be defined as an ability to see the interrelationship of mathematical concept and an ability to see the interrelationship between mathematics with other fields both with other subjects and with daily life. Bruner stated that in mathematics, every concept relates to the other concept, so is the others, for example between postulates, between thories, between topics, and between other mathematics branches for example between algebra and geometry (Ruseffendi, 1988). Therefore, in order for students to be able to succeed more in learning mathematics, students should be given more opportunity to observe the interrelationship.

There are two general mathematical connections i.e. modeling connections and mathematical connections. Modeling connection is the relationship between the situation of problems occured in the daily life or in other disciplines with its mathematical representation; meanwhile, 
mathematical connection is the relationship between two equivalent representations and between the solving process of each representation. Lestari (2014) states that mathematical connection ability is a high level thinking ability which should be developed because in mathematics learning, every concept is interrelated to the other concept. This mathematical connection ability will give a more meaningful learning for the students so that it could help the students in understanding the interrelationship between concepts. Mathematical connection ability is classified into three types, they are: 1) Connection between mathematical concepts i.e. mathematical material or topic that has many connection on one to another. This connection between mathematical concept can help students to be able to connect the topics; 2) Connection with other disciplines outside mathematics i.e. mathematics relates to the other subjects that students have known or will know such as physics, economy, social study, and science; 3) Connection with the real world or the daily life i.e. indicating that mathematics can be connected to the problem solving of daily life issues (NCTM in Harahap, 2015).

Indicator of mathematical connection ability according to NCTM (2003) includes identifying and using the interrelationship between mathematical ideas, understanding how mathematical ideas connected and developed one to another so it is tied completely, identifying and using mathematics in the concept outside mathematics.In line with that, Sumarmo (2005) suggests some indicators to asses students' mathematical connection ability, they are: 1) identifying equivalent representation of same concept; 2) identifying the relationship of a representation's mathematical procedure to the equivalent representation procedure; 3 ) use and assess the interrelationship between mathematical topics and interrelationship outside mathematics; and 4) use mathematics in the daily life. The indicators of mathematical connection ability used in the present study refer to the indicators made by NCTM in which the connection ability that will be assed is by connecting mathematical topics, connecting mathematics with other subject, and connecting mathematics with the real world or the students' daily life. To evaluate students' mathematical connection ability, scoring guide called as holistic scale from North Carolina Department of Public Instruction (in Ratnaningsih, 2003) is used as shown in the table below:

Table 1. Scoring Guideline of Mathematical Connection Questions

\begin{tabular}{|l|c|}
\hline $\begin{array}{l}\text { Students Respond to the } \\
\text { Questions }\end{array}$ & Score \\
\hline $\begin{array}{l}\text { No answer/answers not relevant } \\
\text { to the questions/no anwers } \\
\text { correct. }\end{array}$ & 0 \\
\hline $\begin{array}{l}\text { Only few of the questions } \\
\text { correctly answered. }\end{array}$ & 1 \\
\hline $\begin{array}{l}\text { Almost all aspect of questions } \\
\text { correctly answered. }\end{array}$ & 2 \\
\hline $\begin{array}{l}\text { All aspect of questions } \\
\text { fully/clearly and correctly } \\
\text { answered. }\end{array}$ & 3 \\
\hline
\end{tabular}

\section{Concrete-Pictorial-Abstract Learning Approach}

(CPA) Concrete-Pictorial-Abstract (CPA) learning approach is also usually called as Concrete-Representational-Abstract (CRA) approach or Concrete-SemiconcreteAbstract (CSA) approach. Neglecting the names, those three learning approaches are similar and initially are based on the thinking of Bruner in 1960. The CPA approach consists of three learning stages, they are: (1) Physical manipulation of concrete materials, (2) Pictorial representation from concrete manipulation, and (3) Problem solving using abstract notation (Witzell, 2005). In line to that, Cooper (2012) explains three orderly stages from the learning with CPA approach, they are: (1) Concrete stage is the first stage which involves students physically interacting by manipulating concrete 
materials (manipulative), (2) pictorial stage is a transition stage which involves students working by representing concrete model which usually in the form of drawing circles, dots, counting, or geometric picture, and (3) Abstract stage is the final stage where a mathematical concept modeled simbolically using numbers, variables, and other mathematical symbols.

The three aforementioned learning stages using CPA approach is a unity which implementation support one another.It is in line with Riccomini et al. (in Yuliawaty, 2011) who states that the three learning stages in CPA approach are integrated, may not be seen separately to ensure students' learning success. Miller and Mercer (in Sousa, 2007) similarly state that each stage in CPA approach constructs the previous learning to enhance the conceptual knowledge and retention in mathematics learning.

Learning with CPA approach provides a conceptual framework to create a meaningful relationship between the stages of concrete, pictorial, and abstract understanding.The learning stages within CPA approach according to Flores (2010) are as follows: (1) Choose concrete materials (manipulative) which will be used to introduce conceptual understanding of a lesson that will be learned by the students; (2) Guide the students to independently participate in using the concrete materials (manipulative) by giving them direction and sign; (3) Change the use of the manipulative materials with pictures or paintings; (4) Use strategy that could help the students memorizing previous learning previously conducted. It functions as a transition process from the use of pictures or paintings to the use of numbers or symbols; and (5) Encourage the students to only use numbers or symbols in completing mathematics exercise given, and this activity is focused on mastery.

In the learning process with CPA approach, it is very possible that students with higher prior mathematical ability (students with high and middle mathematical prior ability) feel no need to use the concrete materials to create manipulative pictures from them or the students feel no need to create pictures to make connection with the abstract concept. However, the activities are needed to be conducted because some experience shows that the aforementioned learning activities allow students to internalize the problem solving process and help them to master the skill to imitate process. It is in line with Anstrom (in Yuliawaty, 2011) who states that such activities conducted in the learning with CPA approach will firm the knowledge background and ensure the students to do reasoning approach and create connection to solve more complex issues.

Learning process with real activity by using concrete materials and pictures when introducing new concepts in mathematics is very important to be conducted. It is in line with Sousa (2007) that the development of cognitive strategy llike the stages of learning with CPA approach needs to be conducted to inform students regarding the technique to solve mathematical issue not only to find the answer.

In the learning process with CPA approach, there is a manipulative aspect which is called to contain advantage and trick at the same time. As a fun factor, learning by using manipulative materials can enhance students' diposition and attitude in class (Goracke in Cooper, 2012). However, the use of manipulative materials has a tricky potential when the students consider the learning as a playing activity rather than as an opportunity to enhance their understanding on mathematics (Mc Neil and Jarvin in Cooper, 2012).

The use of manipulative materials in mathematics learning is an important process to help students understand the mathematics concepts they are learning. It is in line with Lidinillah (2009) that mathematics learning should be able to bridge chidren's thinking ability which still in the level of concrete operational with 
mathematics which conceptually abstract. Therefore, manipulative materials can be used as a bridge to connect concrete to abstract way of thinking. Moreover Hartshom et al. (in Yuliawaty, 2011) states that implementing idea in mathematics is difficult because some mathematics concepts are very "abstract". One of practical ways to give a meaningful learning experience is by using the manipulative materials.

The importance of the use of manipulative materials is also stated by Skemp (in Turmudi, 2012) that manipulative materials in mathematics learning can be used as a foundation to learn more abstract lesson. It is in line with Bruner (in Suwangsih, 2012) who states that interaction with manipulated concrete materials can help students memorizing and implementing mathematics ideas learned in solving the issue in real world correctly. Similarly, Brownell (in Suwangsih, 2012) states that the use of concrete materials to be manipulated can help students to understand the meaning of concept and skill learned. Therefore according to the aforementioned studies, the use of concrete materials to be manipulated can be very meaningful in the effort to develop and enhance students' mathematical ability.

After conduct a learning with CPA approach, it is possible to happen that students cannot solve the abstract problem successfully. To the case like this, teacher should identify the reason why the students do not understand the concept.Ricomini (2010) advices, as follows: (1) teach again the concept in concrete level; (2) teach again the concept in representation level; (3)give students opportunity to speak with their own words in explaining the solution and how they got it. Therefore, it suggests that if the students do not show pictorial level mastery, the learning is back to the concrete level. Likewise, when the students do not show abstract level mastery, the learning is back to the pictorial level.

Learning with CPA approach is advantageous for most students and has been proven effective to help students who have difficulty in learning mathematics because this CPA approach is gradual from learning through real materials to through pictures then through symbols (Jordan, Miller, and Mercer in Sousa, 2007). Students often feel frustrated when teacher gives a mathematical issue only in abstract form. Teacher needs to develop concept to control mathematical content and to provide teaching which allow students to process new learning more meaningfully and effectively.

Some studies support the effectivity of the approach, for example the study of Witzel (2005) to the six and seven grade students who are identified to have difficulty in algebra learning. Students who learn how to solve algebra equation transformation through CPA approach obtain higher test result than the class control students (received traditional teaching). In addition, students using CPA approach make less prosedural mistake when solving algebraic variables (Wizel, Mercer, and Miller in Sousa, 2007).

Findings in Yuliawaty (2011) suggest that the enhancement of understanding ability and mathematical problem solving of junior high school students who receive learning through CPA approach is better than students who receive conventional learning.Moreover, study of Yeo et al. (2005) which conducted to students of Tamasek Junior College Singapore found that the learning with CPA approach could help the students who have difficulty in visualizing and connecting to correct a certain integral statement and evaluating volume in higher level of calculus. The findings in Putri (2015) concluded that the ability of mathematical representation, spatial sense, and selfefficacy of students who are going to be elementary school teachers in a public university in West Java, Indonesia with CPA approach enhance than the students who receive conventional learning.

Therefore, it can be concluded that learning with CPA approach is a learning 
approach which pays attention to the order of the three learning stages, starting from the use of concrete materials, then students are given opportunity to create pictorial representation from the concrete materials, and finally students work in abstract notation. It is expected that by doing the three learning stages, students will understand the mathematical concepts clearly and correctly and feel direct advantage when learning mathematics.

\section{The interrelationship between mathematical connection ability and the Concrete-Pictorial-Abstract (CPA) approach}

The indicators of mathematical connection ability that will be assed in the present study are students' ability to relate mathematics topics, to relate mathematics with other subjects, and to relate mathematics with real world or the students' daily life. To enhance the abilities, CPA approach is used in the learning in the class. The first stage in learning with CPA approach is learning with concrete materials. The use of concrete materials will certainly help students to enhance their ability to relate mathematics with the real world. The second stage is pictorial, in this stage the students are given opportunity to make representation of real materials by using pictures. Pictures that the students make function as a connecting bridge between real world and abstract mathematics. The learning in this stage will help students to enhance their ability to relate mathematics with other subjects of other disciplines. The last learning stage is abstract stage, in this stage students will learn using abstract mathematical symbols. The learning in this stage will give opportunity to students to enhance their ability to relate mathematical topics. Therefore, every learning activity designed within CPA approach is predicted to be able to enhance students' mathematical connection ability.

\section{RESEARCH METHOD}

The present study is a quasi experiment study with pretest and posttest control groups. Ruseffendi (1998: 45) describes such study as follows:

$$
\begin{array}{lll}
\mathrm{O} & \mathrm{X} & \mathrm{O} \\
\mathrm{O} & & \mathrm{O}
\end{array}
$$

Note: $\mathrm{O}=$ Test (pretest and posttest)

$\mathrm{X}=$ Mathematics learning using CPA approach

The study is conducted with two learning groups that are learning group with CPA approach as an experiment group and conventional learning as a control group.

The population in the present study is all elementary school students in Purwakarta district, West Java province, Indonesia.The sample is the fifth grade students of SDN 10 Ciseureuh and SDN Cibatu of Purwakarta district. Subjects whom becoming sample of the present study are 39 students which consist of 20 students in experiment group and 19 students in control group. Students in the experiment group will receive learning with CPA approach and students in the control group will receive conventional learning. The instrument used is mathematical conection ability test. The test is given in the beginning and in the end of learning both for the experiment and control groups of students.

\section{FINDING AND DISCUSSION}

The ehancement of students' mathematical connection ability is observed from the normalized gain $(\mathrm{N}$ gain). The enhancement criterion is classified based on the criterion suggested by Hake (in Meltzer, 2002) as follows:

Table 2. Criterion of Students' Mathematical Connection Ability

\begin{tabular}{|c|c|}
\hline $\begin{array}{c}\text { Enhancement } \\
\text { Interval }\end{array}$ & $\begin{array}{c}\text { Enhancement } \\
\text { Criterion }\end{array}$ \\
\hline $\mathrm{N}$-gain $>0,7$ & High \\
\hline $0,3<\mathrm{N}$-gain $\leq 0,7$ & Middle \\
\hline $\mathrm{N}$-gain $\leq 0,3$ & Low \\
\hline
\end{tabular}


The recapitulation of analysis result of students' $\mathrm{N}$-gain based on the learning both as a whole and according to Mathematical Prior Ability (MPA) is presented in the following table.

Table 3. Enhancement Average of Mathematical Connection Ability Based on MPA and as a Whole

\begin{tabular}{|c|c|c|c|c|}
\hline \multirow{3}{*}{ Learning } & \multicolumn{4}{|c|}{ Average } \\
\cline { 2 - 5 } & \multirow{2}{*}{ Whole } & \multicolumn{3}{|c|}{ MPA Group } \\
\cline { 3 - 5 } & & High & Middle & Low \\
\hline CPA & 0,738 & 0,822 & 0,711 & 0,736 \\
\hline Conventional & 0,735 & 0,771 & 0,897 & 0,382 \\
\hline
\end{tabular}

The data in the table describes that the average enhancement of students' mathematical connection ability seen as a whole does not show any difference. Students with high and low MPA who receive CPA learning approach obtain higher mathematical connection ability than the students who receive conventional learning. Students with middle MPA experience opposite situation, the enhancement of students' mathematical connection ability is higher in students with conventional learning than students with CPA learning approach. Based on the Ngain criterion, it is known that the average enhancement of mathematical connection ability as a whole is high in both types of learning for students with high and middle MPA. Meanwhile for the low MPA students, enhancement of mathematical connection ability is high in the CPA learning approach and middle in conventional learning.

To test the significance of the average difference of mathematical connection ability enhancement, test of average difference is conducted. The result of test of average difference with level of significance $95 \%$ shows that if observed as a whole and from high MPA students group, there is no significant difference of mathematical connection ability between students with CPA and conventional learning. In middle MPA students group, the result of test of average difference shows a significant difference in which the mathematical connection ability of students who receive conventional learning is significantly better than students who get CPA learning approach. Test of average difference of mathematical connection ability of students with low MPA shows a significant difference in which mathematical connection ability of students with CPA learning approachis significantly better than students with conventional learning. Therefore, it can be stated that the implementation of CPA approach significantly influences the mathematical connection ability of students with low MPA.

\section{Discussion}

Descriptive study shows that the enhancement of mathematical connection ability in students who receive CPAlearning approachis better than students who receive conventional learning, except to the group of middle MPA students where oppossite finding derived. This finding is in line with Witzel (2005) who concluded that the sixth and seventh grade students in United States who get CPA approach learning achieve better learning result in algebra than students who get conventional learning. Putri (2015) also concluded that the mathematical representation ability of students who are going to be elementary school teacherswith CPA learning approach is better than students with conventional learning.

The enhance of mathematical connection ability of students who get CPAlearning approach isbetter than students with conventional learning because the learning stages in CPA approach give opportunity to the students to develop new knowledge by creating a connection with their prior knowledge. It is in line with Miller and Mercer (in Sousa, 2007) which suggest that every stage in CPA develop previous learning to motivate students' learning, memorizing ability, and to construct conceptual knowledge.

The first stage in CPA learning approach is the use of concrete materials 
which can be manipulated that can help students to prepare themselves to learn more abstract concept.It is in line with Skemp (in Turmudi, 2012) which suggests that the use of manipulativematerials in learning can serve as a foundation for further learning in more abstract level.

In line with this, Bruner (in Suwangsih, 2012) states that interaction with manipulated concrete materials will firm the concept understanding and help students to memorize ideas learned easier and to apply it in real situation appropriately. Furthermore, the second stage in CPA learning is pictorial where students are trained to transfer their mathematical ability from concrete to symbolic representation (abstract). In the learning process in this stage, students are trained to represent their various mathematical ideas by making pictures, diagrams, graphics, tables, symbols, or mathematic models, designing problem solving in mathematics, making questions or explanation verbally and written with their own language related to the process and result of mathematical problem solution derived.It is in line with NCTM (2000) which states that the representation of physical materials, pictures, diagrams, graphics, and symbols help students to communicate their thoughts. Therefore, it is learning circumstance through such stages in CPA learning approach that makes students able to enhance their mathematical connection ability more than students with conventional learning.The highest enhancement of mathematical connection ability is achieved by students from high MPA group.This situation is very possible to happen because according to Arends (in Yumiati, 2015), the ability to learn new ideasdepends on earlier previous ability and existing cognitive structure. It is in line with Sweller (1998) who states that students with high MPA have low cognitive burden because they have already had many schemesabout mathematic concept which ease them to master mathematic ability. Therefore, it is unsurprising that students in high MPA group get higher achievement and enhancement of mathematical connection ability than students in middle or low MPA groups. It is certainly influenced by theirprior ability which eases them to learn something new.

The achievement and enhancement of mathematical connection ability of students with low MPA are better than middle MPA group in CPA learning approach. It is possible to happen because stages in CPA learning approach give opportunity for the low achiever students to understand the concept that is taught more easily.

Learning stages which are begun by manipulating concrete materials continued by representing concrete models which are usually pictorial such as circles, dots, or geometric pictures, and continued to abstract stage in which mathematic concept is modelled symbolically to help students retain memory of a concept then develop description of that concept understanding process to their way of thinking.It is in line with Jordan, Miller, and Mercer (in Sousa, 2007) who state that CPA approach is benefitting most student and proven very effective in helping students who have mathematics learning difficultiesbecause this CPA approach moves gradually from the real materials to pictures and then to symbols. Therefore, it is obvious that the three stages in CPA give students with low ability opportunity to develop their mathematical connection ability.

It is observed that the low achievement and enhancement of mathematical connection ability of middle MPA students than low MPA students are because during the learning process, many middle achiever studentsseemed to be less enthusiast in the learning process of manipulating concrete materials and making pictures out of them; meanwhile, it is different with the low achiever students, they learned very enthusiastically when given opportunity to manipulate concrete materials and then to make pictures of them. Low achiever studentsare often seen 
to try to use the concrete materials to understand and to solve issues presented in the worksheet, sometimes they are seen and heard asking question to the high achieverstudents, and discuss their thoughts to their friends in the group. Middle achiever students are trapped in a condition where they feel no need to follow the learning stages by using manipulative materials, while the use of manipulative materials (concrete materials) will be very helpful in firming mathematical concept understanding. It is in line with Lidinillah (2009) who state that manipulative materials can be used as a bridge to connect concrete to abstract way of thinking. Similar to Kelly (2006), manipulative materials can be used to help students understand the process of problem solving related to mathematical concept or topic.

Based on the interview result, students from low MPA group feelmore helped in understanding mathematical concept by having a learning opportunity manipulating the concrete materials directly and turning them into pictures.These activities help firming their understanding about mathematical concept they are learning. Meanwhile, middle achiever students tend to ignore the learning process by using concrete materials, they feel that the learning with concrete materials is playing activity. This middle MPA students' pressumption could trap the students to notseriously study so that the enhancement of mathematical connection ability of middle MPA students is lower than low MPA students. The situation is in line with Mc Neil and Jarvin (in Cooper, 2012) which state that the use of manipulative materials contains a tricky potential for the students when they consider it to be a playing activity to fill the time rather than to provide an opportunity to enhance their mathematical understanding.

From all the explanation above, it can be concluded that the implementation of CPA learning approach can be used as one of the techniques to enhance students' mathematical connection ability especially for students with low mathematical prior ability. The use of manipulative materials (concrete) that are varied and challenging the students' way of thinking is also needed so that the students do not trap in a monoton and boring learning situation.

\section{CONCLUSION}

All in all, according to the findings and discussion of the present study, it can be concluded that CPA approach is very good to be implemented to enhance students' mathematical connection ability especially for students with low mathematical prior ability (MPA).The enhance of mathematical connection ability of students with low MPA who receive CPA learning approach is high; meanwhile, the enhancemet of mathematical connection ability of students who receive conventional learning is found in students with middle MPA.

\section{REFERENCE}

Cooper, E. T. (2012). Using Virtual Manipulatives with Pre-service Mathematics Teachers to Create Representational Models. International Journal for Technology in Mathematics Education, Vol 19, No 3. [Online]. Diakses dari https://ehis-ebscohostcom.ezp.lib.unimelb.edu.au/eds/pdf viewer /pdfviewer?vid=6\&sid=cd03d4951f99-4ec2-90d5-85ac8c67257b $\% 40$ se ssionmgr115\&hid $=5$.

Desmita. (2008). Psikologi Perkembangan. Bandung: ROSDA.

Depdiknas. (2006). Kurikulum Tingkat Satuan Pelajaran. Jakarta: Depdiknas.

Dwirahayu, G. (2012). Pengaruh Strategi Pembelajaran Eksploratif terhadap Peningkatan Kemampuan Visualisasi, Pemahaman Konsep Geometri, dan Karakter Siswa. (Disertasi). Sekolah Pascasarjana, 
Universitas Pendidikan Indonesia, Bandung.

Flores, M. M. (2010). Using the ConcreteRepresentational-Abstract

Sequence to Teach Subtraction With Regrouping to Students at Risk for Failure. Journal: Remedial and Special Education, Volume 31 Number 3 May/June 2010 195-207. [Online]. Diakses dari http://resource binder 802a.wikispaces.com/file/view/Eff ective+Math+ Strategies+CRA.pdf.

Harahap, T. H. (2015). Penerapan Contextual Teaching and Learning untuk Meningkatkan Kemampuan Koneksi dan Representasi Matematika Siswa Kelas VII-2 SMP Nurhasanah Medan Tahun Pelajaran 2012/2013. Jurnal EduTech, 1(1), hlm. 1-19. Dipetik Maret 25, 2016, dari http://jurnal.umsu.ac.id/index.php/e dutech/article/download/273/pdf_2.

Kelly, C. A. (2006). Using Manipulative in Mathematical Problem Solving: A Performance Based Analysis. [Online]. Diakses dari http://www.math.

edu/tmme/tmmevol3no2_colorado_ pp184_193.pdf.

Lestari, K. E. (2014). Implementasi BrainBased Learning untuk Meningkatkan Kemampuan Koneksi dan Kemampuan Berpikir Kritis serta Motivasi Belajar Siswa SMP. Jurnal Pendidikan Unsika, 2(1), hlm. 36-46. Dipetik Maret 25, 2016, dari http://journal.unsika.ac.id/index.ph p/judika/article/view/120.

Lidinillah. (2009). Alat Peraga Manipulatif dalam Pembelajaran Pemecahan Masalah Matematika di Sekolah Dasar. [Online]. Diakses dari http://abdulmuizlidinillah.wordpres s.com.

Meltzer, D.E. (2002). Addenum to:The Relationship between Mathematics Preparation and Conceptual
Learning Gain in Physics: A Possible "Hidden Variable" in Diagnostics Pretest Scores. [Online]. Diakses dari http://www.physics.iastate.edu/per/ docs/Addendum_on_normalized_g ain.pdf\#search $=\% 22$ meltzer $\% 2 \mathrm{C} \%$ $202002 \% 2 \mathrm{C} \% 20$ gain $\% 2 \mathrm{C} \% 20 \mathrm{a} \% 2$ 0possible\%20hidden \%20variable\% 22.

NCTM. (2003). Program for Initial Preperation of Mathematics Specialists. [Online]. Diakses darihttp://www.ncate.org/LinkClic $\mathrm{k} \quad$.aspx?fileticket $=\% 2 \mathrm{Frfx}$ 5Ju56RY\%3D\&tabid $=676$.

NCTM. (2000). Using the NCTM 2000 Principles and Standards with The Learning from Assessmentmaterials. [Online]. Diakses dari http://www wested.org /lfa /NCTM2000.PDF.

Permendikbud. Nomor 81A Tahun 2013 tentang Implementasi Kurikulum 2013.

Putri, H.E. (2015). Penagaruh Pendekatan Concrete-Pictorial-Abstract (CPA) terhadap Peningkatan Kemampuan Representasi Mathematis, Spatial Sense, dan Self-Efficacy Mahasiswa Calon Guru Sekolah Dasar. (Disertasi). Sekolah Pascasarjana, Universitas Pendidikan Indonesia, Bandung.

Putri, H. E. (2015). The Influence of Concrete-Pictorial-Abstract (CPA) Approach to The Mathematical Representation Ability Achievement of the Pre-Service Teachers at Elementary School. International Journal of Education and Research, 3(6), P.113-126.

Ratnaningsih, N. (2003). Mengembangkan Kemampuan Berpikir Matematik Siswa SMU melalui Pembelajaran Berbasis Masalah. Bandung: (Tesis) PPs UPI. Tidak diterbitkan.

Ruseffendi, E. T. (1988). Pengantar kepada Membantu Guru Mengembangkan Kompetensinya 
dalam Pengajaran Matematika untuk Menigkatkan CBSA. Bandung: Tarsito.

Ruseffendi, E. T. (1998). Statistika Dasar untuk Penelitian Pendidikan. Bandung: IKIP Bandung Press.

Saptini, D. R. (2016). Penerapan Pendekatan CPA untuk Meningkatkan Kemampuan Koneksi Matematis Siswa SD. Purwakarta: (Skripsi) UPI Kampus Purwakarta. Tidak diterbitkan.

Sousa, D. A. (2007). The ConcretePictorial-Abstract Approach. [Online]. Diakses dari http://www.logan schools.org/mathframework/CPA.p df.

Sumarmo, U. (2005). "Pembelajaran Matematika untuk Mendukung Pelaksanaan Kurikulum Tahun 2002 Sekolah Menengah”. Makalah pada Seminar Pendidikan Matematika 7 Agustus 2005 Universitas Negeri Gorontalo, Gorontalo.

Surya, E. (2013). Peningkatan Kemampuan Representasi Visual Thinking pada Pemecahan Masalah Matematis dan Kemandirian Belajar Siswa SMP melalui Pembelajaran Kontekstual. (Disertasi). Sekolah Pascasarjana, Universitas Pendidikan Indonesia, Bandung.

Suwandari, D. W. (2015). Penerapan Pendekatan Kontekstual untuk Meningkatkan Kemampuan Koneksi Matematis Siswa SD. Purwakarta: Skripsi UPI Kampus Purwakarta. Tidak diterbitkan.

Suwangsih, E. (2012). Teori-teori Belajar dalam Pembelajaran Matematika. Subang: Royyan Press.

Sweller, J. (1998). Cognitive Load during Problem Solving: Effect on Learning. Cognitive Science, 1(2), hlm.257-285.

Turmudi. (2012). Matematika Landasan Filosofis, Didaktis, dan Pedagogis Pembelajaran Matematika untuk
Siswa Sekolah Dasar. Jakarta: Direktorat Jenderal Pendidikan Islam, Kementerian Agama RI.

Witzel, W. S. (2005). Using CRA to Teach Algebra to Students with Math Difficulties in Inclusive Settings. A Contemporary Journal, 3(2), hlm. 49-60, 2005 .[Online]. Diakses dari https://ehis-ebscohost-com.ezp. lib.unimelb.edu.au/eds/pdf viewer/p dfviewer?vid $=7 \&$ sid $=$ cd03d495 1f99-4ec2-90d5-

$85 \mathrm{ac} 8 \mathrm{c} 67257 \mathrm{~b} \% 40$

sessionmgr $115 \&$ hid $=116$.

Yeo, C. J. Wong, C. M., dan Ho, F. H. (2005). Concrete-PictorialAbstract (CPA) Approach for Teaching Volume of Revulotion in Advanced Level Mathematics. [Online]. Diakses dari http://www.ijstr.org/finalprint/may2018/Concrete-pictorialabstract-Approach-On-StudentsAttitude-And-Performance-InMathematics.pdf

Yuliawaty, L. (2011). Pembelajaran Matematika dengan Pendekatan CRA (Concrete-RepresentationalAbstract) untuk Meningkatkan Kemampuan Pemahaman dan Pemecahan Masalah Matematik Siswa SMP. (Tesis). Sekolah Pascasarjana, Universitas Pendidikan Indonesia, Bandung.

Yumiati. (2015). Meningkatkan Kemampuan Berpikir Aljabar, Berpikir Kritis Matematis, dan SelfRegulated Learning Siswa Melalui Pembelajaran CORE. (Disertasi). Sekolah Pascasarjana, Universitas Pendidikan Indonesia, Bandung. 